\title{
Political appointees in executive government: Exploring and explaining roles using a large-N survey in Norway
}

Jostein Askim, Rune Karlsen \& Kristoffer Kolltveit, Public Administration, 2017

\begin{abstract}
Political appointees in executive government have received increased scholarly attention in recent years. However, few studies have covered non-Westminster systems, and apart from classifications that systemize variation in assignments, theorizing about appointees has been limited. Using large-N survey data, the article finds three distinct roles among political appointees in Norway: 'stand in', 'media advisor' and 'political coordinator'. The article then combines insights from research on political appointees with insights from core executive studies (CES) to explain why political appointees perform one role or another. The empirical results support the notion that roles of appointees within the core executive depend on where they sit, supporting the asymmetric power model within CES. The results also show that appointees' roles within the executive depend on their personal experience, supporting the notion of a resource exchange between ministers and their appointees in the mould of the resource-dependency perspective within CES.
\end{abstract}

\section{Acknowledgements}

Previous versions of this article have been presented at seminars at KU Leuven 3-4. November 2015 and Hertie School of Governance 19. November 2015. The authors would like to thank the participants at these events, as well as the journal's three anonymous reviewers for their helpful comments and advice. Thanks also to Ingvild Våset Thorsen for research assistance. The study has been funded by research grants from the Department of Political Science, University of Oslo and from the Research Council of Norway's DEMOS program ('På toppen av styringssystemet').

\section{Introduction}

Political appointees as a third element in executive government have received increased scholarly attention in recent years (Shaw and Eichbaum 2015a). Much empirical research has focused on political appointees' backgrounds, what motivates them for service, what tasks they perform in the executive, and what they do after their work in government. These studies have shown that appointees' assignments vary across and within countries. To systemize, scholars have introduced various classifications of tasks and functions (see for instance Connaughton 2010a, 2010b, 2015; Eichbaum and Shaw 2011; Maley 2000, 2011; OECD 
2007). Apart from such classifications, theorizing about political appointees is limited. Furthermore, most of these studies cover Westminster systems. Notable exceptions, focusing on multi-party consociational systems, include Brans, Pelgrim and Hoet (2006), Ullström (2011), and Gouglas (2015). Limitations in the empirical evidence base, and the lack of attempts to theorize about the arrangements, relationships, and roles of political appointees, have led Shaw and Eichbaum (2015a, p. 1) to call for studies with higher theoretical ambitions and data from other countries.

We aim to answer this call by using large-N survey data and statistical methods from a parliamentary system where minority and coalition governments are the norm. We study political appointees in the Norwegian parliamentary system, something that has not been done systematically since the early 1970s (Eliassen 1972). Our data derive from a 2015 survey of more than 200 state secretaries and political advisors from two coalition cabinets (2001-2005 and 2005-2013).

We pursue three questions. First: What are the most important tasks political appointees carry out? Beyond Westminster settings, much is still unknown regarding the contribution political appointees make to the procedural dimensions of policymaking (Shaw and Eichbaum 2015a). Here we investigate tasks performed and types of advice offered by political appointees in Norway, a country with long traditions of political appointees. Our second research question is: Do patterns of tasks performed constitute distinct roles? To test if roles are distinct, it is necessary to investigate whether correlations between behavioural items (various types of tasks performed and types of advice offered to the minister) reflect some underlying dimensions. This investigation, in turn, necessitates large-N survey data and statistical analysis. We use factor analysis on the survey data, and identify three distinct roles performed by political appointees in the Norwegian executive.

Our third research question is: What explains which roles political appointees occupy? 
Research on political advisors is rich in empirical description and typologies, but has said little about why political appointees do what they do in different countries and political systems (see, however, some discussion in Eichbaum and Shaw (2011) and Peters and Pierre (2004)). We develop an analytical framework with three sets of explanations. We then investigate, using OLS regression analysis, to what extent this framework can explain the distribution of roles among political appointees in Norwegian executive government. The first set of explanations in the framework is supply, referring to the idea that what role a political appointee is deployed to perform is contingent upon his or her personal background and experience. The second is demand, referring to the idea that an appointee's role is contingent also upon what ministers lack in their own experience. The third is formal structure, referring to the idea that power is asymmetrically distributed and follows structural arrangements such as type of ministry and the appointee's formal position.

The analytical framework combines insights from research on political advisors with insights from core executive studies (CES), thereby attempting to create closer ties between the empirical work on political appointees and established theories within political science and public administration. CES is a stream of political science emerging (predominantly) from studies of the British central government: the institutions, networks and practices surrounding the prime minister, cabinet, and cabinet committees - the heart of the executive machinery (Rhodes 1995). CES has rarely covered the roles of political appointees such as policy advisors (but see Craft 2015; Connaughton 2015; Shaw and Eichbaum 2014). The basis of executive power is a central theme within CES (see Elgie 2011; Shaw 2015). Rhodes has advocated a resource-dependency perspective, which emphasizes that actors are dependent on each other to achieve their goals, so they must exchange resources. Power is thus relational and more dispersed than structural arrangements would suggest (Rhodes 1995, 1997, 2007). Others have put forward an asymmetric power model, as an adaptation of 
Rhodes' perspective. The model essentially asserts that power within the executive is locational and a function of structural or institutional attributes, making power relations within the core executive asymmetrical (Marsh, Richards and Smith 2003; Heffernan 2003). In our framework, we suggest that supply and demand capture the resource-dependency perspective within CES, while formal structure reflects the asymmetric power model.

The remainder of the article is organised as follows: In the first section we review key literature on political appointees. In the second we develop the three perspectives used to explain differences in roles. The third section contains our findings. In the final section we discuss the relevance of our results for the literature on political appointees and CES.

\section{What political appointees do in executive government}

Here 'political appointee in executive government' is a person working in a ministry's political leadership section, appointed by a cabinet minister, and tasked with serving as the minister's personal advisor and aid in running the ministry. Unlike civil servants, political appointees are recruited on political criteria, not on merit-based criteria, and their positions are not permanent; political appointees leave their positions when their ministers so decide, or when their ministers resign. Across different jurisdictions, political appointees can be called state secretaries, political advisors, ministerial advisors, special advisors, political experts, or press secretaries. The existing literature offers good overviews of how political appointees function in various countries and political systems. Some contributions focus on appointees' tasks and assignments. Maley (2000), for instance, shows how Australian ministerial advisors help their ministers and the cabinet generate policy ideas, formulate policy, and provide policy advice. Shaw and Eichbaum (2014) show how political advisors in New Zealand read, interpret and forward advice from civil servants, attend meetings with civil servants, and participate in meetings with other ministers. Research from the 
Scandinavian countries suggests that political appointees might have considerable executive powers and contribute to executive policymaking (Ullström 2011).

Some scholars have paid particular attention to advice-type tasks, and have suggested classifications of the types of advice political appointees give to their ministers. Among the most elaborate is Craft and Howlett's (2012, p. 91) classification, which distinguishes between the content and the time frame of appointees' advice, ending up with four categories: pure political and policy-process advice, medium- to long-term policy-steering advice, shortterm crisis and firefighting advice, and evidence-based policymaking.

Other contributions concern the impact of the work political appointees do. Eichbaum and Shaw (2007, p. 624) show how political appointees might act as a filter between ministers and civil servants. Political appointees also help solve disagreements between parties in a coalition. In New Zealand, for instance, almost two thirds of the political advisors reported that they frequently assisted with consultations within the government coalition (Eichbaum and Shaw 2011).

Some contributions attempt to reduce variability in tasks and to conceptualize and classify political appointees' underlying roles. Maley (2000) identifies five policy roles performed by ministerial advisors in Australia: some appointees are agenda-setters; some link ideas, interests and opportunities; some mobilize; some bargain; and some deliver (i.e., implement policies). Connaughton identifies four roles performed by Irish ministerial advisors - experts, partisans, coordinators and minders - where being a minder involves looking out for 'issues that may be potentially harmful to ministers' (Connaughton 2010b, p. 352). Research in the United Kingdom (LSE GV314 Group 2012, p. 5) has identified three roles performed by British special advisors: wonks (who provide advice on how policies could and should be developed), enforcers (who ensure that policies are implemented), and fixers (who do political jobs like meeting with party colleagues and writing political speeches). 
Some of these role classifications are based on political appointees' backgrounds working on the assumption that appointees' educational and professional experience strongly influences the services they provide (OECD 2011, p. 18). Others have defined roles using appointees' own assessments regarding the effects of what they do in executive government (Connaughton 2010b). However, as several scholars emphasize, roles can also be constituted by actual behaviour. When discussing the role concept in studies of legislatures, Andeweg (2014) shows how some writers exclude behaviour as part of a role, while others include it. Searing (1991), for instance, emphasizes how roles are defined by personal goals, attitudes and behaviour of people in particular positions and settings. According to this 'behavioural' perspective, roles should not be constructed only from norms or decision rules connected to the position; nor should they solely be constructed from politicians' own assessments - roles that exist in the minds of politicians (Searing 1991, p. 1251). Roles of political appointees should rather be constructed 'from below', and be deduced from appointees' actual behaviour in what Searing calls 'the political reality'. We follow this strategy here, and investigate whether variations in a large number of observed behavioural items (tasks performed and types of advice offered) reflect (in factor analysis parlance) variations in a lower number of unobserved underlying factors, which we label 'roles'.

\section{Explaining the roles of political appointees}

The importance of political appointees varies considerably between countries. So far, few contributions have systematically investigated differences between and within countries, that is, what might decide which political appointees end up performing the various roles, such as who carries bags, who gives advice, and who participates actively in executive policymaking. Research has often focused on correlations between the backgrounds of political appointees and the contents of their work in the executive. However, the roles of political appointees 
depend on a number of other factors too. In the following, three broad explanatory perspectives are introduced to systemize explanations of the roles of political appointees.

\section{Formal perspective on roles}

The formal perspective on roles relates to what the political appointees are and where they are situated. According to this explanation, political appointees' roles are determined by their formal positions. In settings with a formal hierarchy between positions, appointees who hold the highest post are expected to wield more influence than those in the more junior positions do. We should however consider it an empirical question whether formal role equals actual role. The relationship is not 1:1 in organizations in general, and clearly not in executive politics, where the number of formal positions below cabinet level is low, and role norms are far less regulated and more diffuse than in, for example, the civil service.

The formal perspective relates also to the ministry in which political appointees serve. The asymmetric power model assumes that ministries' characteristics influence the role and power of their inhabitants (Marsh et al. 2003). CES scholars argue that some ministries are more powerful than others (Marsh et al. 2003, p. 322); power thus depends on where actors are to be found within the core - whether actors are at the centre or on the periphery of core executive networks (Elgie 2011; Heffernan 2003, p. 348). Besides in the prime minister's

office, essential resources are generally to be found in the ministry of finance (or the chancellor of the exchequer), as no other ministers are involved in all aspects of cabinet life (Marsh et al. 2003; Elgie 1997; Larsson 1993).

How then does the type of ministry relate to the type of role for political appointees? As Maley, for example, notes in her study into the work of Australian political staff, some ministry portfolios have higher levels of complexity and conflict than others (2015). Policy 
advisors in those ministries 'had to be very active in pushing the agenda and they worked closely together with the department in "hand-to-hand combat" with other political players" (Maley 2015, p. 47). Ministerial advisors in spending portfolios had to be active 'because of the need to win money or avoid cuts in cabinet' (Maley 2015, p. 47). Maley concludes that ' $[\mathrm{t}]$ he standing of the minister and the portfolio within the cabinet could make a big difference to how much time advisers spent fighting, either to achieve an agenda or to stave off the directives of more powerful ministers' (2015, p. 47).

Following the asymmetric power model, one could argue that political appointees at the centre could have more resources than other political appointees have (Craft 2015, p. 58). Regarding political appointees' roles, we follow Maley, however, and would argue that political appointees in the Prime Minister's Office and the Ministry of Finance will have less independence vis-à-vis their ministers, given those ministries’ importance. The same argument might be used regarding the complexity of the ministry. In ministries with high policy complexity, it is more feasible for ministers to give political appointees responsibility for part of the ministry, and to receive technical and professional advice on complicated issues.

\section{Supply perspective on roles}

The supply perspective on roles relates to who the political appointees are. The focus on demographic variables such as education and work experience is well known from several studies of civil servants' attitudes and behaviour (see for instance Christensen and Lægreid 2009; Jacobsen 2006). In organizational theory, the term 'organizational demography' has often referred to attributes such as employees' age, sex, and education (Pfeffer 1982, p. 277). Within CES, the resource-dependency perspective stresses that actors are dependent on each other and must exchange resources, for instance expertise (Rhodes 1997). Applying that 
interpretation here, the policy knowledge and expertise of political appointees would influence their role within the executive.

In research on political advisers, political appointees who contribute specialist knowledge and expertise have been labelled 'experts' or 'policy experts' (Connaughton 2015; Maley 2015). 'Partisans', on the other hand, are appointed predominantly because of their political background (Connaughton 2010a). Some studies also show that the level of education varies. In Ireland about one third of the advisors held a master's degree (Connaughton 2010b, p. 354), while Eichbaum and Shaw in the New Zealand case found that about two thirds of the advisors held at least one postgraduate qualification (2007, p. 97).

We expect there to be a link between appointees' background and the roles they perform in government. If political appointees have higher education, we would expect them more often to give professional advice and to be handed responsibility for part of the ministry as policy experts. We apply the same argument regarding experience (tenure). If political appointees have long tenure, we expect them to have some specialist role because of their knowledge gained through work in executive government. We also expect that political appointees who previously held party positions will undertake 'work of a politically partisan nature' (Connaughton 2010a, p. 62).

Demand perspective on roles

By 'demand' we focus on what ministers need from their political appointees according to what they lack in their own experience. According to this explanation, ministers' backgrounds will shape political appointees' roles. This understanding can also be drawn from the resource-dependency perspective, as the 'demand' side is also part of the resource exchange between ministers and their political appointees. As suggested by Maley (2015, p. 47) and Shaw and Eichbaum (2014), experienced senior ministers have other needs than their less experienced colleagues do: 
[I]t seems reasonable to suggest that more senior or influential ministers might be motivated to appoint advisers with skills sets differing [from] those [advisors] appointed by junior or less influential colleagues (...), and to deploy them somewhat differently (Shaw and Eichbaum 2014, p. 22).

We conceptualize ministers' experience as the relationship between a minister's current portfolio and his or her experience, or lack of such, from former cabinets. If ministers lack portfolio experience, we expect their political appointees to be deployed and to act as policy experts. If ministers lack cabinet experience, we expect their political appointees to be deployed and to act as partisans offering political-tactical advice. Finally we incorporate whether or not an appointee's minister is party leader. Party leaders are presumably busier than other ministers are, since they have two roles, and can therefore be expected to delegate more decision-making authority to their political appointees than do ministers who are not party leaders.

\section{Research setting: Executive government in Norway}

Norway is a parliamentary democracy that frequently has coalition cabinets. Even though political appointees have been few in number (Dahlström 2009), Norway has a long tradition of having them in executive government, and there are two political positions: political advisors and state secretaries. The political advisor position has existed since the early 1990s, and is a continuation and re-labelling of the personal secretary position, introduced in 1946 as a provisional arrangement to unburden the busiest ministers. The Norwegian Constitution does not mention the political advisor position. According to government regulations, the political advisor should be at the personal disposal of the minister, and should perform tasks the minister delegates. However, it is emphasized that political advisors cannot have 
independent decision-making authority (Ministry of Government Administration and Consumer Affairs 1981). Political advisors are formally appointed by the Prime Minister's Office.

Reducing the ministers' workloads was the explicit reason for establishing the position of state secretary in 1947. The increasing scope of the state's activity had made ministers' workloads unreasonably heavy, and the position of state secretary was introduced so that ministers could avoid being 'trapped' inside ministries (Askim, Karlsen and Kolltveit 2014). State secretaries are mentioned in the Constitution; they are not part of the cabinet, but can act on behalf of the minister, at the minister's discretion. State secretaries are supposed to assist the minister in leading the ministry. However, how much decision-making power is delegated to state secretaries varies from minister to minister. State secretaries are appointed by the Council of State.

In Norway, the number of political appointees has grown over the last decades. The number of political advisors peaked at the end of the 1990s with an average of 1.5 political advisors for each minister. During the period 2000-2013 the number has decreased, and Norwegian ministers now have only one political advisor each. The number of state secretaries has grown steadily, and it is now common to have an average of 2.5 state secretaries for each minister (Askim et al. 2014).

In the Norwegian parliamentary democracy, sectoral ministries are strong, reflecting the principle of ministerial responsibility, where ministers are constitutionally responsible to parliament for all activities in their ministries and the ministries' subordinate bodies. There are few formal requirements on horizontal coordination, leaving much room for actors like state secretaries and political advisors to participate in coordination processes between ministries. The Prime Minister's Office functions as both a secretariat for the prime minister and a support for the cabinet. The Norwegian Prime Minister's Office has traditionally been 
comparatively small, although it has gradually been expanded to increase horizontal coordination (Christensen and Lægreid 2002).

While Norwegian ministers are at the apex of the executive government, the ministries are administratively led by secretaries general (departementsråder). These top civil servants are subordinate to their ministers, but function as the ministers' advisors on administrative questions. Ministerial communication departments grew considerably between 1995 and the end of 2000. While there were about 40-50 such civil servants in the mid-1990s, this group grew to about 120 by 2010 (Mjelva 2011). Since the mid-2000s, about half of the ministries have also recruited civil servants as speechwriters for their ministers.

\section{Methods and data}

Data for measuring the study's dependent variables come from a survey distributed by the authors to 283 individuals who had served as state secretary or political advisor in one of the last two Norwegian governments: the Bondevik II government that sat from 2001 to 2005 and the Stoltenberg II government that sat two terms from 2005 to 2013. Bondevik II was a minority coalition cabinet consisting of the Conservative Party, the Christian Democratic Party and the Liberal Party. Stoltenberg II was a majority coalition cabinet, consisting of the Labour Party as senior partner, the Socialist Left Party and the Centre Party.

We collected the names (using register data from Norwegian Social Science Data Services - NSD) and contact information for all political appointees in the two cabinets. The survey was distributed by e-mail to the respondents (using Questback) in early 2015. After two probes the response rate reached 73 per cent (206 individual responses), and the frequency of non-response to individual questions was negligible. The response rate was higher among appointees in Stoltenberg II (76\%) than in Bondevik II (65\%). No other indications of analytically important bias have been found in the sample. 
Former surveys to Norwegian political and administrative elites have also yielded high response rates, although rarely this high. The high response rate to the present survey might be explained by the fact that unlike, for example, ministers, MPs and top civil servants, Norwegian state secretaries and political advisors have never been studied by using surveys; therefore, survey exhaustion was not a problem. Also, respondents were not serving as appointees in the executive when they received the survey. Although incumbent appointees might be better equipped to answer reliably questions about their daily work, the disadvantage of relying on memory data was traded for the advantage of former political appointees' higher willingness to 'speak freely' and to participate in the survey.

The survey consisted of 24 batteries of questions. Here we mainly use two batteries related to assignments undertaken and types of advice political appointees offer. Respondents were asked to answer according to their experience in their last position, since some had more than one.

To explain why appointees end up in different roles we apply three explanatory perspectives: supply, formal structure, and demand. For the supply perspective - appointees' characteristics - we have included three variables: 'education' $(1=$ master or doctorate, $0=$ no postgrad degree), 'party experience', and 'government experience'. The 'party experience' variable is an additive index consisting of dummies for whether respondents had filled all or any of six party positions before serving as appointees in the executive (including local or county government mayor, MP, and parliamentary advisor). The 'government experience' variable is measured as the time spent as state secretary or political advisor in former cabinets (number of days divided by 30), using bibliographic data collected from registers.

For the formal structure perspective we include three variables. 'Position' is measured as the respondent serving as either state secretary $(=0)$ or political advisor $(=1)$. To measure the ministry variable 'core', we follow Druckman and Warwick (2005, p. 41), and define the 
Prime Minister's Office and the Ministry of Finance as the most important ministries in Norway. We include whether respondents served as appointees in the core executive $(=1)$ or in non-core ministries $(=0)$. As for 'ministry complexity', some scholars have used the number of executive agencies organizationally under the ministry as a measure of complexity (Indridason and Kam 2008). Instead, we measure complexity as the size of the ministry (the number of civil servants).

For the demand perspective we focus on the minister. Data on former portfolio and cabinet experience of the ministers the respondents served under was retrieved through bibliographic data available in registers and was coded as two dummies: Has the minister whom the respondent served as state secretary or political adviser been a minister before, in another cabinet $(1=$ yes, $0=$ no) ? And has the minister led the same ministry before $(1=$ yes, $0=$ no)? We have also included whether or not the minister the respondent served under was party leader too $(1=$ yes, $0=$ no $)$.

\section{Empirical Analysis}

The empirical analysis is divided into three parts, according to the research questions elaborated above. First we investigate what tasks Norwegian political appointees carry out and what type of advice they give to ministers. Then we study the relationship between different tasks and advice, and explore if there are patterns that constitute roles. In the third part we explain variances in roles by using the framework developed above.

\section{Tasks and assignments of political appointees}

As discussed above, political appointees carry out a variety of assignments. Using previous research and our own knowledge of Norwegian politics and ministries, we asked respondents about the extent and importance of 11 specific activities. Table 1 shows results. 
Not all tasks are carried out by all political appointees. Almost all of them gave politicaltactical advice on single issues, kept in contact with the parliamentary group and party organization, and gave the minister advice on various issues in the ministry. Relatively few relieved the minister by having responsibility for parts of the ministry or by fronting ministerial issues in the media. Note that the political appointees consider it more important to give what we have called political-tactical advice than to give policy advice on single cases, thereby suggesting that political appointees in Norway are political experts rather than policy experts.

[Table 1 here]

\section{Searching for roles}

We investigated the relationship between tasks and advice by using factor analysis $-\mathrm{a}$ technique suitable for exploring if the relationships between variables constitute a smaller number of underlying dimensions (Foster 2006). A principal component strategy and an open solution returned two dimensions with an eigenvalue above 1, the suggested level from the methodological literature, and a third dimension with a value just below 1 . Next, we asked for a solution that identified three dimensions. Table 2 presents the results. According to the content of the dimensions, we label the roles as 'stand in', 'media advisor' and 'political coordinator'.

[Table 2 here]

The first underlying dimension (role) consists of policy-related tasks and advice, as well as tasks that involve substantial independence from the minister. Appointees who have this role 
have been delegated political responsibility for parts of the ministry, and are specialists within a field, able to provide professional advice to their ministers. They also front issues in the media, which supports the interpretation that they have been delegated responsibility for a policy area. We have labelled the role 'stand-in' minister.

The second role concerns externally oriented political communication. An important part of this role is to coordinate between the ministry's political leadership and communication unit, to prepare the minister's speeches and newspaper op-eds, and to give advice on how to handle urgent media issues. This role should not be seen as an expression of political appointees as bag carriers, but rather as an expression of the need for ministers and ministries to have political appointees also dealing with media and communication issues. Hence, we label this role 'media advisor': an advisor who handles the minister's public communications.

The third role is more related to politics. Here giving political-tactical advice as well as giving long-term political advice is essential. These political appointees also participate in coordination processes in the government apparatus. This role can be characterized as that of someone working closely with ministers and giving them political-strategic advice; therefore, we label it 'political coordinator'.

\section{Explaining the roles of political appointees}

To calculate respondents' values on the roles identified by the factor analysis, we construct three indexes using the three items that define the dimensions in the factor analysis (largest factor score and clearest factor structure). We choose three items so we can include the same number of items in each index. A reliability test (Chronbach's alpha) suggests that these indexes' internal consistency is good. The alpha is .77 for the 'stand in' index, .73 for the 'media advisor' index, and .67 for the 'political coordinator' index. The relatively low alpha for the last index reflects the low eigenvalue in the factor analysis. The correlation between 
the 'stand in' index and the 'media advisor' index is negative (-.21), indicating that these are two distinct roles. The 'political coordinator' index, however, has a weak positive correlation (.30) with both the other two indexes, thus indicating some overlap with the other two roles. The three indexes have 13-point scales (0-12). Mean values on the scales are 7.4 for the 'stand in' index, 8.8 for the 'media advisor' index, and 9.7 for the 'political coordinator' index. As indicated also by single-item values displayed in Table 1, these index values show that the 'stand in' role is least common, and that the 'political coordinator' is most common role for Norwegian political appointees.

We want to explain why political appointees end up in different roles, and suggested three explanatory perspectives: supply, formal structure and demand. Table 3 presents results of a stepwise multivariate regression analysis where we study effects of these groups of independent variables on functioning as a 'stand in', 'media advisor' and 'political coordinator'. In addition to independent variables subsumed under the three explanatory perspectives (supply, formal structure and demand), we include gender and age as control variables. The appended Table A2 presents bivariate relationships between the independent and dependent variables.

[Table 3]

Our model explains variation in all three roles. However, the model is far better at explaining the 'stand in' role than at explaining the other two roles. The explained variance for the full model is .46 for 'stand in' and significantly less for 'media advisor' (.15) and 'political coordinator' (.11).

Formal structure is the strongest explanatory perspective, and the formal position of appointees is the strongest explanatory variable, influencing all three roles. Unsurprisingly, 
being a state secretary is essential for having the 'stand in' role, while the 'media advisor' role is mostly carried out by political advisors. State secretaries are also more likely than political advisors to have the 'political coordinator' role, but the relatively small effect indicates that giving political-tactical advice and helping coordinate policy are done by both state secretaries and political advisors. 'Political coordinators' are also found to a greater extent in the Ministry of Finance and at the Prime Minister's Office (the core), while 'stand ins' are found outside the core executive ministries. Surprisingly, ministry size seems to have a small negative effect on the 'media advisor' role, indicating that this role is important in both small and large ministries.

The supply perspective also has great explanatory power - especially for 'stand ins' and 'political coordinators'. Higher education and more government experience are important for the 'stand in' role. These background characteristics are related to formal position, as the effects of both variables weaken when position is introduced in the model. Having experience from executive government is also important for the 'political coordinator' role. Surprisingly, party experience has no significant effect on the 'political coordinator' role. There is a (negative) bivariate relationship between 'stand in' and party experience, but this effect disappears when we introduce the other variables.

Ministers' demands, as measured by our model, seem to have little effect on why appointees do what they do in executive government. In the bivariate regression, for appointees carrying out the 'political coordinator' role, there are weak effects of ministers' experience. But as we see from model IV in Table 3, these effects do not hold when we introduce the other variables, and the bivariate relationship is therefore most likely spurious.

Of the control variables, only age is significant, as younger political appointees are more prone to having a 'media advisor' role. We also checked for differences between the two studied cabinets, but there was no effect on any of the three roles. 


\section{Discussion}

More and less exclusive tasks

Some tasks, like giving ministers political-tactical advice on single issues and liaising with the mother party on the minister's behalf, are performed by virtually all political appointees (both political advisors and state secretaries). Among the tasks we have examined, fronting ministerial issues in the media is the task fewest Norwegian political appointees perform on a regular basis. All news consumers witness that state secretaries perform this task occasionally. However, few appear in the media regularly enough to function as de facto minister for a specific policy issue (to 'front an issue' in communications parlance). A second task that is performed regularly by few (at least fewer than half of all) political appointees is that of having responsibility for parts of the ministry. Performing this task regularly is related to 'media forefronting' in that it makes civil servants and the media perceive the appointee as de facto minister on an issue or a set of issues.

Regarding advice, although the differences are not very large, short-term procedural (political tactics) advice is the type of advice ministers receive most often from their political appointees, and short-term substantive advice is the type they receive least often. This pattern is unsurprising, given that the latter type of advice is available to ministers from civil servants, while alternative sources for the first type are few. The surprise is rather that the difference is not larger in the two polar-opposite types of advice from appointees. That ministers use so many political appointees as sources of advice on policy contents might support the impression that political appointees break the civil service monopoly over advice, affecting the neutral expertise and competence of civil servants in ministries (Craft 2013; Hustedt and Salomonsen 2014). A more positive interpretation would be that political appointees inject important contestability, with their checks and balances on advice ministers 
receive from the civil service (Shaw and Eichbaum 2014, p. 610).

Our survey did not include menial tasks such as keeping ministers' calendars updated (or carrying their bags (Finch 1996)), and that is a limitation in our research design. The impression from respondents' free-text comments to the survey, however, is that bagcarrying-type tasks are comparable to the high-end tasks just discussed: they are performed regularly by only a minority of political appointees - albeit by the least influential rather than the most influential ones.

\section{Division of labour: Distinct roles for political appointees}

The results indicate that political appointees do have specific roles. Political appointees perform many tasks only occasionally, but many appointees still have a clear profile. We read Maley's (2015) analysis of appointees in the executive in Australia as somewhat differing from our analysis. She finds that appointees' roles are not fixed, and that what appointees do varies by arena. The difference in findings might suggest that division of labour is clearer among Norwegian than among Australian political appointees, but the studies' methodologies are insufficiently similar to warrant strong comparative conclusions. Moreover, as discussed, although a three-role pattern is clear, the roles we uncover are not totally distinct, but somewhat overlap.

Note that we used factor analysis to check, for state secretaries only, the dimensionality of tasks and advice. This analysis returns much the same results, as does the initial analysis of all political appointees. The different items constitute the same dimensions, but the 'media advisor' role is most distinct, most likely because few state secretaries carry out this role.

The limited number of questions regarding tasks and assignments also affects the number of roles we can find. In other words, if there are 'bag carriers' (Finch 1996) among Norwegian political advisors or (less likely) among state secretaries, we have not found them, 
because we have not looked for them. Some political advisors do score low on all our measures of high-status tasks, which suggests that we could add bag carrier to our role set. However, we would need positive measures of bag carrying (minding ministers' calendars, etc.) before we could conclude that a fourth role exists. Low scores on our measures of highstatus tasks do not preclude the possibility that someone would also score low on measures of low-status tasks; some might simply not be useful appointees. More questions on tasks and advice might also have yielded more roles, and might have better aligned the Norwegian case with the five-role typology from Australia (Maley 2000), or the four-role typology from Ireland (Connaughton 2010a). Studies in countries with Napoleonic and Germanic administrative traditions, with higher numbers of political appointees, and therefore potentially having a more fine-grained division of labour, might yield a higher number of distinct roles. It is possible, for example, that political coordination vis-à-vis other ministries and coordination vis-à-vis parliament will be two distinct roles in a system with more political appointees in the executive, rather than two aspects of one role, as is the case in Norway.

Why do political appointees' roles differ?

The multivariate analysis showed that our analytical model with three groups of independent variables fared well, suggesting that the model might be useful as a starting point for explaining appointees' roles in other countries too. The full model explained 16 per cent ('political coordinator'), 19 per cent ('media advisor') and 48 per cent ('stand in') of the variance across the three roles, the last obviously strongly supporting the model.

Perhaps unsurprisingly, the full model is relatively best fit to explain who becomes 'stand in' - irrespective of whether the units of observation are state secretaries or all political appointees in the executive. First, 'political coordinator' is a less well-defined role construct 
than the others (see results section), making it difficult to explain who performs it. Second, to explain who becomes 'media advisor', the model would probably require other measures (independent variables), especially under the supply perspective. For example, experience from news media or communication consulting could be deemed essential for serving as ministers' 'media advisors'.

If we compare the explanatory power of the three perspectives, the formal perspective is clearly a stronger predictor of political appointees' roles in the executive than the other two perspectives are. The ministry's complexity (size) hardly affects what roles political appointees perform, but the ministry's centrality in the government apparatus does: appointees do not function as 'stand ins' in ministries defined as core. Furthermore, appointees' rank and title (being state secretary or political advisor) matter for the roles they perform. Unsurprisingly, one's formal role affects one's actual role when working in the public sector - for example, having a higher rank usually means that one exercises more power. However, there are large differences in roles amongst political advisors (the lower rank) and state secretaries (the higher rank) respectively, and some political advisors wield more power than some state secretaries do. The model also has considerable explanatory power and returns very similar results when tested on state secretaries alone (see Table A3).

Supply, meaning the qualifications and resources appointees bring with them, is also a significant predictor of appointees' roles, especially for whether an appointee performs as the minister's 'stand in'. Among our supply measures, former experience in government (as state secretary or political appointee) affects both the 'stand in' role and the 'political coordinator' role. Higher education affects the 'stand in' role, suggesting that the (few) actors given responsibility for parts of the ministry usually have an expert background. The surprise is perhaps that party experience seemingly does not affect the 'political coordinator' role.

The demand perspective lacks any explanatory power in the present analysis. Our findings 
suggest that ministers who are short on political or substantive/topical experience do not use their state secretaries and political advisors any differently than do ministers with more such experience. On current evidence, the demand dimension adds theoretical complexity without improving explanatory power. However, one could argue that our measures of demand are few and weak. As Shaw and Eichbaum argue (2014), measures of what resource exchange the civil service needs from its political leaders could be included. They argue that sometimes the civil service lacks - for example - experienced, skilled policy analysts, and so ministers might need to add such competence by way of political appointees.

Somewhat surprisingly, we found no differences between the two cabinets studied. One could expect more political coordinators amongst political appointees in the Bondevik II cabinet given that a minority government must stitch together a legislative majority. However, the majority coalition of Stoltenberg II also needed a good deal of political coordination. It consisted of parties with significant political differences, something that necessitated political coordination across ministries and also coordination towards the coalition parties' parliamentary groups.

\section{Conclusion}

We have found, using factor analysis and substantive interpretation, three roles among political appointees in the Norwegian executive: 'stand in', 'media advisor' and 'political coordinator'. Although drawn from the Norwegian case, this set of roles has generic qualities, in our opinion. Virtually all modern democracies have experienced strong media pressure, increasing the need for coordinated political communication. In governments where civil servants are heads of communication, as in Norway's, we would expect ministers to give appointees considerable responsibility for externally oriented political communication.

Likewise, in systems without formal deputy ministers, we would expect some political 
appointees to be 'stand ins', in charge of parts of the ministry's portfolio, easing ministers' burdens. We also expect 'political coordinators' to be found outside of the Norwegian context as tasks constituting this role are of general importance. However this role's importance and extent will most likely vary between systems and different types of cabinets. For example, we believe 'political coordinators' to be more essential in coalition than in single-party cabinets. Although studies in countries with higher numbers of political appointees and studies that include questions regarding tasks beyond those studied here might have yielded a higher number of distinct roles, the set of roles uncovered in our research might inspire development of similar role typologies elsewhere, using similar methodology. Initially, we argued that roles should be inferred from behaviour, and the results indicate that this indeed is a fruitful approach and a way forward. However, the behaviour-based roles uncovered in the empirical analysis are partly explained by appointees' background, giving some support to the assumption we questioned - that political appointees' educational and professional experience reflects 'the services they provide' (OECD 2011, p. 18). However, the formal perspective more strongly predicts a political appointee's role in the executive than the other two perspectives do.

Our study suggests two implications for core executive studies. First, Craft (2015) has argued for updating the 'gospel', i.e. to broaden which actors that are part of the core executive, as the initial concept did not include appointed political staff in ministries. To include these actors, argues Craft, would make the framework better suited for understanding policy coordination within the executive (2015: 64). We support this reconceptualization of the core executive. Our study shows that political appointees are important not only for advising their minster or participating in coordination processes; some even have decisionmaking power within the executive. To broaden research beyond Westminster systems, CES should consider, first, which tasks that are essential in the core executive, and then include in 
comparative studies the actors that perform these tasks, be they ministers, political appointees, or top civil servants.

As for the discussions within CES about what constitutes the basis for power, the results from our study are mixed. One interpretation is that the Norwegian case supports the notion that the role of political appointees within the core executive depends on where they sit, supporting the asymmetric power model, as advocated by Marsh et al. (2003). Our results thus echo findings from Britain, where political appointees have been shown to have different roles in different ministries (Marsh et al. 2003, p. 321). However, our study also shows that roles are relational - they depend on appointees' personal background and experience too. This supports the notion of a resource exchange within the executive between ministers and their appointees (Shaw and Eichbaum 2014, pp. 603-606) in the mould of Rhodes' resourcedependency perspective $(1997,2007)$. Consequently, both perspectives are needed to understand distribution of power within the executive; they should be considered complementary rather than competing.

Shaw and Eichbaum (2015b) conclude International Journal of Public Administration's special issue on 'Political Staff in Executive Government' by calling for a theoretical turn in this field. Our contribution has been to develop, and to test, an analytical framework for explaining why some political appointees perform different roles. Future research that compares political systems and investigates under what conditions different factors explain roles political appointees perform in executive government, will supplement with macro-level explanations the micro-level factors we have focused on here. 


\section{References}

Andeweg, R. 2014. 'Roles in legislatures', in M. Shane, T. Saalfeld and K.W. Strøm (eds), The Oxford Handbook of Legislative Studies. Oxford: Oxford University Press.

Askim, J., Karlsen, R. and Kolltveit, K. 2014. 'Statssekretærer i norsk politikk: De oversette maktutøverne'[State secretaries in Norwegian politics: The overlooked power-wielders], Norsk Statsvitenskapelig Tidsskrift, 30, 4, 233-55.

Brans, M., Pelgrims, C. and Hoet, D. 2006. 'Comparative Observations on Tensions between Professional Policy Advice and Political Control in the Low Countries', International Review of Administrative Sciences, 72, 1, 57-71.

Christensen, T. and Lægreid, P. 2002. Reformer og lederskap. Omstilling i den utøvende makt [Reforms and leadership. Changes in executive government]. Oslo: Universitetsforlaget.

Christensen, T. and Lægreid, P. 2009. 'Living in the Past? Change and Continuity on the Norwegian Central Civil Service', Public Administration Review, 69, 5, 1-11.

Connaughton, B. 2010a. 'Minding the minister: Conceptualising the role of the special adviser in Ireland', Administration, 58, 1, 55-75.

Connaughton, B. 2010b. 'Glorified Gofers, Policy Experts or Good Generalists: A Classification of the Roles of the Irish Ministerial Adviser', Irish Political Studies, 25, 3, 347-69.

Connaughton, B. 2015. 'Navigating the Borderlines of Politics and Administration: Reflections on the Role of Ministerial Advisers', International Journal of Public Administration, 38, 1, 37-45.

Craft, J. 2013. 'Appointed political staffs and the diversification of policy advisory sources: Theory and evidence from Canada', Policy and Society, 32, 3, 211-23.

Craft, J. 2015. 'Revisiting the Gospel: Appointed Political Staffs and Core Executive Policy Coordination', International Journal of Public Administration, 38, 1, 56-65. 
Craft, J. and Howlett, M. 2012. 'Policy formulation, governance shifts and policy influence: Location and content in policy advisory systems', Journal of Public Policy, 32, 02, 79-98.

Dahlström, C. 2009. Political appointments in 18 Democracies. QoG Working paper series, (18), pp. 1-19.

Druckman, J.N. and Warwick, P.V. 2005. 'The missing piece: Measuring portfolio salience in Western European parliamentary democracies', European Journal of Political Research $44,1,17-42$.

Eichbaum, C. and Shaw, R. 2007. 'Ministerial Advisers and the Politics of Policy-Making: Bureaucratic Permanence and Popular Control', Australian Journal of Public Administration, 66, 4, 453-67.

Eichbaum, C. and Shaw, R. 2011. 'Political Staff in Executive Government: Conceptualising and Mapping Roles within the Core Executive', Australian Journal of Political Science, $46,4,583-600$.

Elgie, R. 1997. 'Models of Executive Politics: A Framework for the Study of Executive Power Relations in Parliamentary and Semi-presidential Regimes', Political Studies XLV, $2,217-31$.

Elgie, R. 2011. 'Core executive studies two decades on', Public Administration, 89, 1, 64-77. Eliassen, K. 1972. 'Statssekretæren - fagmann eller politiker. En undersøkelse av rekrutteringen til statssekretærembetet i Norge' [The state secretary - expert or politician. A study of the recruitment of state secretaries in Norway], Tidsskrift for samfunnsforskning, 13, 1, 51-68.

Finch, T. 1996. 'Linchpin or bag carrier? A study of the importance of the role of the parliamentary private secretary to the prime minister', Journal of Legislative Studies, 2, 2, $110-23$. 
Foster, J.J. 2006. 'Factor Analysis', in V. Jupp (ed.), The Sage Dictionary of Social Research Methods. London: Sage.

Gouglas, A. 2015. 'Greek Ministerial Advisers: Policy Managers, Not Experts?', International Journal of Public Administration, 38, 1, 15-27.

Heffernan, R. 2003. 'Prime ministerial predominance? Core executive politics in the UK', British Journal of Politics and International Relations, 5, 3, 347-72.

Hustedt, T. and Salomonsen, H.H. 2014. 'Ensuring political responsiveness: Politicization mechanisms in ministerial bureaucracies', International Review of Administrative Sciences, 80, 4, 746-65.

Indridason, I.H. and Kam, C. 2008. 'Cabinet Reshuffles and Ministerial Drift', British Journal of Political Science, 38, 04, 621-56.

Jacobsen, D.I. 2006. 'The relationship between politics and administration: The importance of contingency factors, formal structure, demography, and time', Governance, 19, 2, 30323.

Larsson, T. 1993. 'The Role and Position of Ministers of Finance', in J. Blondel and F. Müller-Rommel (eds), Governing Together: The Extent and Limits of Joint DecisionMaking in Western European Cabinets. New York: St. Martin's Press, pp. 207-22.

LSE GV314 Group. 2012. 'New life at the top: Special advisers in British Government', Parliamentary Affairs, 65, 4, 715-32.

Maley, M. 2000. 'Conceptualising Advisers' Policy Work: The Distinctive Policy Roles of Ministerial Advisers in the Keating Government, 1991-96', Australian Journal of Political Science, 35, 3, 449-70.

Maley, M. 2011. 'Strategic Links in a Cut-Throat World: Rethinking the Role and Relationships of Australian Ministerial Staff', Public Administration, 89, 4, 1469-88. Maley, M. 2015. 'The Policy Work of Australian Political Staff', International Journal of 
Public Administration, 38, 1, 46-55.

Marsh, D., Richards, D. and Smith, M. 2003. 'Unequal Plurality: Towards an Asymmetric Power Model of British Politics', Government and Opposition, 38, 3, 306-32.

Ministry of Government Administration and Consumer Affairs. 1981. Reglement for departementenes organisasjon og saksbehandling [Rules for organization and case handling in ministries]. Oslo: Forbruker- og administrasjonsdepartementet.

Mjelva, S.U. 2011. I spenningsfeltet mellom forvaltning og politikk. En studie av departementenes kommunikasjonsenheter [Between administration and politics. A study of ministerial communications departments]. Masters' thesis. Oslo: Department of Political Science, University of Oslo.

OECD (Organisation for Economic Co-operation and Development). 2007. Political advisers and civil servants in European countries. Sigma Papers, No. 38. France. SIGMA paper no. 38, Paris: OECD Publishing.

OECD (Organisation for Economic Co-operation and Development). 2011. Ministerial advisors: Role, influence and management. Paris: OECD Publishing.

Peters, B.G. and Pierre, J. 2004. 'Politicization of the civil service: concepts, causes, consequences', in B.G. Peters and J. Pierre (eds), Politicization of the Civil Service in Comparative Perspective, London: Routledge, pp. 1-13.

Pfeffer, J. 1982. Organizations and organization theory. Boston, MA: Pitman.

Rhodes, R.A.W. 1995. 'From Prime ministerial power to core executive', in R.A.W. Rhodes and P. Dunleavy (eds), Prime Minister, cabinet and core executive. London: Macmillan.

Rhodes, R.A.W. 1997. 'Shackling the leader? Coherence, capacity and the hollow crown', in H. Bakvis, P. Weller, and R.A.W. Rhodes (eds), The hollow crown. Countervailing trends in core executives. London: Macmillan. 
Rhodes, R.A.W. 2007. Understanding governance: Ten years on. Organization Studies, 28, $12,43-64$.

Searing, D. 1991. 'Roles, rules, and rationality in the new institutionalism', American Political Science Review, 85, 4, 1239-60.

Shaw, R. 2015. 'Raising the Bar: Core Executive Studies, Public Value and a Changing World', Political Studies Review, 13, 4, 520-33.

Shaw, R. and Eichbaum, C. 2014. 'Ministers, Minders and the Core Executive: Why Ministers Appoint Political Advisers in Westminster Contexts', Parliamentary Affairs, 67, $3,584-616$.

Shaw, R. and Eichbaum, C. 2015a. 'Follow the Yellow Brick Road: New Directions in Studying Political Advisers in Executive Government', International Journal of Public Administration, 38, 1, 1-3.

Shaw, R. and Eichbaum, C. 2015b. 'Following the Yellow Brick Road: Theorizing the Third Element in Executive Government', International Journal of Public Administration, 38, 1, $66-74$.

Ullström, A. 2011. Styrning bakom kulisserna, Regeringskansliets politiska staber och regeringens styrningskapacitet [Steering from backstage. The government's political staff and the steering capacity]. Stockholm Studies in Politics, no. 138, Stockholm: Department of Political Science, Stockholm University. 
Table 1: Tasks, assignments and advice of political appointees in Norway (2001-2013); scale from 1 to 5; frequency and mean

\begin{tabular}{|c|c|c|c|c|c|c|}
\hline & \multirow{2}{*}{$\begin{array}{c}\text { Little } \\
\text { extent/not } \\
\text { important at } \\
\text { all } \\
\mathbf{1}\end{array}$} & \multirow[b]{2}{*}{2} & \multirow[b]{2}{*}{3} & \multicolumn{3}{|c|}{$\begin{array}{c}\text { Great } \\
\text { extent/very } \\
\text { important }\end{array}$} \\
\hline & & & & 4 & 5 & Mean \\
\hline Political-tactical advice on single issues ${ }^{\mathrm{a}}$ & 1 & 3 & 3 & 38 & 55 & 4.44 \\
\hline $\begin{array}{l}\text { Keep contact with parliamentary group and party } \\
\text { organization }^{t}\end{array}$ & 0 & 1 & 14 & 33 & 52 & 4.35 \\
\hline $\begin{array}{l}\text { Advise the minister on various issues in the } \\
\text { ministry }\end{array}$ & 1 & 4 & 12 & 34 & 48 & 4.25 \\
\hline Long term political advice ${ }^{\mathrm{a}}$ & 1 & 6 & 10 & 38 & 45 & 4.19 \\
\hline Advice in handling of urgent media issues ${ }^{\mathrm{a}}$ & 0 & 10 & 9 & 37 & 44 & 4.15 \\
\hline $\begin{array}{l}\text { Participate in coordination processes in the } \\
\text { government apparatus }\end{array}$ & 2 & 4 & 22 & 37 & 36 & 4.01 \\
\hline Policy-substance advice on single issues ${ }^{\mathrm{a}}$ & 2 & 10 & 11 & 40 & 36 & 3.96 \\
\hline $\begin{array}{l}\text { Coordinate towards the communications } \\
\text { department in the ministry }\end{array}$ & 2 & 7 & 27 & 25 & 39 & 3.94 \\
\hline $\begin{array}{l}\text { Prepare the minister's speeches and newspaper op- } \\
\text { eds }^{t}\end{array}$ & - & 14 & 24 & 30 & 30 & 3.71 \\
\hline $\begin{array}{l}\text { Relieve the minister by having responsibility for } \\
\text { parts of the ministry }{ }^{t}\end{array}$ & 12 & 15 & 16 & 21 & 37 & 3.57 \\
\hline Front issues in the media ${ }^{\mathrm{t}}$ & 11 & 27 & 34 & 17 & 10 & 2.88 \\
\hline
\end{tabular}

${ }^{t}$ Question: To what extent did you have the following tasks and assignments? Five-point scale (not at all, to a small extent, to some extent, to a large extent, to a very large extent)

${ }^{a}$ Question: How important was it to give the following advice to your minister? Five-point scale (not important at all, less important, neither nor, quite important, very important)

Table 2: Three distinct roles; factor analysis

\begin{tabular}{llll}
\hline & 'Stand in' & $\begin{array}{c}\text { 'Media } \\
\text { advisor' }\end{array}$ & $\begin{array}{c}\text { 'Political } \\
\text { coordinator' }\end{array}$ \\
\hline Relieve the minister by having responsibility for parts of the ministry & 0.84 & -0.24 & 0.16 \\
Front issues in the media & 0.80 & -0.04 & 0.04 \\
Policy-substance advice on single issues & 0.73 & -0.12 & 0.14 \\
Advise the minister on various issues in the ministry & 0.62 & 0.20 & 0.40 \\
Coordinate towards the communications department in the ministry & -0.02 & 0.87 & -0.03 \\
Prepare the minister's speeches and newspaper op-eds & -0.24 & 0.74 & 0.05 \\
Advice in handling of urgent media issues & 0.12 & 0.72 & 0.26 \\
Keep contact with parliamentary group and party organization & -0.15 & 0.61 & 0.28 \\
Political-tactical advice on single issues & 0.13 & 0.18 & 0.80 \\
Long term political advice & 0.08 & 0.29 & 0.78 \\
Participate in coordination processes in the government apparatus & 0.26 & -0.04 & 0.67 \\
\hline Eigenvalue & 3.18 & 2.79 & .96 \\
\hline N
\end{tabular}

$\mathrm{N}=191$ 
Table 3: Explaining the roles of political appointees. Multivariate regression (OLS). Entries are b-coefficients.

\begin{tabular}{|c|c|c|c|c|}
\hline & \multicolumn{4}{|c|}{ 'Stand in' } \\
\hline & I & II & III & IV \\
\hline Constant & 5.801 & 4.303 & 3.971 & 4.204 \\
\hline Gender & -.135 & -.105 & .034 & -.047 \\
\hline Age & $.097 * * *$ & $.050 * *$ & -.010 & -.010 \\
\hline Education & & .601 & .546 & .520 \\
\hline Leader position & & $1.227 * * *$ & $.662 *$ & $.699 *$ \\
\hline Government experience & & $.052 * * *$ & $.029 * * *$ & $.030 * * *$ \\
\hline Party ties & & -.182 & -.109 & -.110 \\
\hline Ministry complexity & & & .001 & .001 \\
\hline Core executive & & & $-1.780 * * *$ & $-1.458 * *$ \\
\hline Position & & & $3.377 * * *$ & $3.394 * * *$ \\
\hline Experience minister 1 & & & & -.249 \\
\hline Experience minister 2 & & & & -.173 \\
\hline Party leader & & & & -.347 \\
\hline \multirow[t]{3}{*}{$\mathrm{R}^{2}$ (adjusted) } & .08 & .27 & .46 & .46 \\
\hline & \multicolumn{4}{|c|}{ 'Media Advisor' } \\
\hline & I & II & III & IV \\
\hline Constant & 10.025 & 10.289 & 11.031 & 10.918 \\
\hline Gender & .178 & .142 & .123 & .110 \\
\hline Age & $-.074 * * *$ & $-.075 * * *$ & $-.046^{* *}$ & $-.048 * *$ \\
\hline Education & & -.521 & -.405 & -.392 \\
\hline Leader position & & .091 & .303 & .338 \\
\hline Government experience & & -.003 & .009 & .010 \\
\hline Party ties & & .131 & .064 & .085 \\
\hline Ministry complexity & & & $-.002 * *$ & $-.002 * *$ \\
\hline Core executive & & & .317 & .558 \\
\hline Position & & & -1.783 & $-1.805 * * *$ \\
\hline Experience minister 1 & & & & .285 \\
\hline Experience minister 2 & & & & -.562 \\
\hline Party leader & & & & -.173 \\
\hline \multirow[t]{3}{*}{$\mathrm{R}^{2}$ (adjusted) } & .06 & .06 & .16 & .15 \\
\hline & \multicolumn{4}{|c|}{ 'Political coordinator' } \\
\hline & I & II & III & IV \\
\hline Constant & 9.404 & 8.661 & 8.921 & 8.915 \\
\hline Gender & -.022 & -.108 & -.204 & -.158 \\
\hline Age & .015 & .002 & -.015 & -.015 \\
\hline Education & & -.241 & -.251 & -.287 \\
\hline Leader position & & .104 & .070 & .044 \\
\hline Government experience & & $.024 * * *$ & $.017 * * *$ & $.015 * *$ \\
\hline Party ties & & .212 & .223 & .215 \\
\hline Ministry complexity & & & -.001 & -.001 \\
\hline Core executive & & & .611 & .476 \\
\hline Position & & & $.814 * *$ & $.881 * *$ \\
\hline Experience minister 1 & & & & .047 \\
\hline Experience minister 2 & & & & .586 \\
\hline Party leader & & & & -.131 \\
\hline $\mathrm{R}^{2}$ (adjusted) & .00 & .07 & .11 & .11 \\
\hline
\end{tabular}

***p < 0.01; **p < 0.05; *p < 0.10.

$\mathrm{N}=195-196$ 
Table A1: Variables and Data Sources

\begin{tabular}{l|c}
\hline Variable & Source \\
\hline Tasks and assignments & Survey \\
Type of advice & Survey \\
Education & Survey \\
Party experience & Survey \\
Government experience & Register data \\
Ministry complexity & Register data \\
Core executive & Survey \\
Position & Survey \\
Experience minister 1 & Register data \\
Experience minister 2 & Register data \\
Party leader & Register data \\
\hline
\end{tabular}

Table A2: Bivariate regressions. Entries are b-coefficients.

\begin{tabular}{l|c|c|c}
\hline & 'Stand in' & 'Media advisor' & $\begin{array}{c}\text { 'Political } \\
\text { coordinator' }\end{array}$ \\
\hline Education & .479 & -.375 & -.344 \\
Leader position & $1.563^{* * *}$ & -.549 & .014 \\
Government experience & $.052^{* *}$ & -.008 & $.024^{* *}$ \\
Party ties & $-.402^{*}$ & .260 & .147 \\
\hline Ministry complexity & $.002^{*}$ & $-.003 * * *$ & $-.002^{* *}$ \\
Core executive & -.838 & .152 & $.997^{* *}$ \\
Position & $-3.852^{* * *}$ & $1.783^{* * *}$ & $-1.002^{* * *}$ \\
\hline Experience minister 1 & -.065 & .091 & .467 \\
Experience minister 2 & -.232 & -.267 & $.852^{*}$ \\
Party leader & -.425 & -.120 & $.594^{*}$ \\
\hline N-197-199
\end{tabular}

$\mathrm{N}=197-199$

Table A3: Explaining the roles of state secretaries. Multivariate regression (OLS). Entries are $b$-coefficients and $R^{2}$.

\begin{tabular}{|c|c|c|c|}
\hline & 'Stand in' & 'Media advisor' & $\begin{array}{c}\text { 'Political } \\
\text { coordinator' }\end{array}$ \\
\hline Constant & $7.948 * * *$ & $9.316 * * *$ & $10.902 * * *$ \\
\hline Gender & -.295 & .092 & -.429 \\
\hline Age & -.011 & -.044 & -.025 \\
\hline Education & .494 & -.382 & $-.523^{*}$ \\
\hline Leader position & $.869 *$ & .258 & -.148 \\
\hline Government experience & $.023 * * *$ & .011 & $.010^{*}$ \\
\hline Party ties & -.154 & .144 & .140 \\
\hline $\begin{array}{l}\text { Ministry complexity } \\
\text { Core executive }\end{array}$ & $\begin{array}{c}.001 \\
-1.398 * *\end{array}$ & $\begin{array}{l}-.004 * * * \\
.273\end{array}$ & $\begin{array}{c}-.002 * \\
.340\end{array}$ \\
\hline Experience minister 1 & -.151 & .217 & -.010 \\
\hline Experience minister 2 & -.245 & -.924 & .145 \\
\hline Party leader & -.481 & .287 & -.016 \\
\hline $\mathrm{R}^{2}$ (adjusted) & .15 & .06 & .06 \\
\hline
\end{tabular}

***p < 0.01; **p < $0.05 ; * \mathrm{p}<0.10$

$\mathrm{N}=133$ 
